\title{
Technical note: Establishment of an ileal cannulation technique in preweaning calves and use of a piecewise regression approach to evaluate effects on growth and pH fluctuation of ileal digesta
}

\author{
I. Ansia, H. H. Stein, M. R. Murphy, and J. K. Drackley* \\ Department of Animal Sciences, University of Illinois, Urbana 61801
}

\section{ABSTRACT}

Digestibilities of nutrients, especially protein, are crucial characteristics of milk replacers in a calf-rearing program. Endogenous synthesis of proteins and microbial fermentation in the large intestine alter apparent total-tract digestibility of AA. Therefore, collection of digesta samples at the end of the ileum is the only method to estimate true small intestinal digestibility of AA. The aim of this work was to evaluate the effectiveness of inserting a T-cannula into the distal ileum of preweaning calves for use in digestibility studies. A second objective was to evaluate the use of a "brokenline" statistical model to compare treatment effects on calf growth and digesta $\mathrm{pH}$. A T-cannula was surgically installed in the terminal ileum of 2 calves approximately $5 \mathrm{~cm}$ anterior to the ileocecal junction at $15 \mathrm{~d}$ of age, and 2 paired noncannulated calves were used as controls. Cannulation did not affect mean body weight $(\mathrm{BW})$, average daily gain, milk and water intakes, and body frame dimensions. However, final BW (89.2 vs. $94.6 \mathrm{~kg}$ ) was lower and starter intake (0.06 vs. 0.21 $\mathrm{kg} / \mathrm{d}$ ) tended to be decreased in cannulated calves compared with control calves. No effects on health scores, rectal temperature, or the odds of incurring diarrhea or being medicated were observed. Flow of digesta (46.4 \pm $0.04 \mathrm{~g} / \mathrm{h}$ ) increased linearly after feeding, whereas there was a quadratic effect of time on digesta $\mathrm{pH}$, with the nadir at approximately $8.5 \mathrm{~h}$ postfeeding. The brokenline model successfully fitted daily fluctuations of $\mathrm{pH}$ and allowed us to detect differences in growth slopes between cannulated and control calves. Despite the expected negative effect on BW, we conclude that this technique permitted sampling of representative ileal digesta while allowing satisfactory growth and health of the calves.

Key words: calf, ileal cannulation

Received April 11, 2019

Accepted July 17, 2019.

*Corresponding author: drackley@illinois.edu

\section{Technical Note}

Calves are born with a reticular groove that enables milk to reach the abomasum, thereby bypassing the rumen (Meale et al., 2017). At birth, the rumen is not completely developed (Baldwin et al., 2004). Although the size (Warner et al., 1956) and metabolic activity of the rumen increase quickly (Rey et al., 2012), the rumen itself is not fully functional until at least $60 \mathrm{~d}$ of age (Eckert et al., 2015). Because of the lack of microbial fermentation in the rumen, preruminant calves rely solely on AA from feed to support growth (Hill et al., 2008). As long as energy is not limiting, body deposition of protein increases linearly as a function of dietary AA absorption (Drackley, 2008).

The use of plant-based protein has increased in the last decades at the expense of milk proteins (Gro Intelligence, 2017). The apparent digestibility of plant protein in milk replacers, however, is generally lower compared with milk proteins (Guilloteau et al., 1986). This difference is caused by several factors, including the effect of protein source on abomasal emptying, digestive secretions, rate of absorption, intestinal morphology and permeability, and flow of digesta (Lallès, 1993; Drackley, 2008). Plant proteins also can decrease apparent digestibility of AA due to a greater synthesis of endogenous protein (Montagne et al., 2000) or because of the presence of antinutritional factors that alter digestive and absorptive capacity of the intestinal epithelium (Lallès et al., 1999). Moreover, microbial fermentation in the large intestine alters the AA profile in feces independent of the dietary AA supply (Khorasani et al., 1989). Consequently, as recommended in pigs (Stein et al., 2007), collecting ileal digesta samples in young preweaning dairy calves is necessary to accurately determine true ileal digestibility of feed ingredients. Research using this technique was abundant in the past (e.g., Smith, 1962; Gorrill and Nicholson, 1972), but to our knowledge only 1 experiment using this technique has been reported in the last 2 decades (Montagne et al., 2003). The considerably greater milk allowance recommended today (Schäff et al., 2018) and 
the availability of nutritive supplements (Górka et al., 2018) and advanced plant-based alternative proteins (Cervantes-Pahm and Stein, 2010; Senevirathne et al., 2017) make it necessary to revisit the digestive physiology of young preruminant calves.

Piecewise or "broken-line" regression models are used with nonlinear data. Broken-line models are characterized by lines or curves connected by joint points called knots (Schwarz, 2015). Each line or curve is a continuous function that represents 1 piece of the polynomial function (Marsh and Cormier, 2002). The knots allow the function to better fit the data (Hurley et al., 2006). Piecewise regression models comprise plateaus $\left(\mathrm{a}_{0}\right)$ and 1 or several slopes $\left(b_{1}, b_{2}\right)$ delimited by knots $\left(x^{\prime}\right)$ plus the error term $\left(\mathrm{e}_{\mathrm{i}}\right)$. The model predicting a dependent variable $\left(\mathrm{y}_{\mathrm{i}}\right)$ from an independent variable $\left(\mathrm{x}_{\mathrm{i}}\right)$ can be written as

$$
\begin{gathered}
\mathrm{y}_{\mathrm{i}}=\mathrm{a}_{0}+\mathrm{b}_{1} \times \operatorname{minimum}\left(\mathrm{x}_{\mathrm{i}}, \mathrm{x}^{\prime}\right) \\
+\mathrm{b}_{2} \times \operatorname{maximum}\left(0, \mathrm{x}_{\mathrm{i}}-\mathrm{x}^{\prime}\right)+\mathrm{e}_{\mathrm{i}} .
\end{gathered}
$$

The best location for a knot can be estimated by parametrically varying $\mathrm{x}^{\prime}$ to find the value that results in the lowest residual sum of squares (Schwarz, 2015).

Our first objective was to adapt and validate a cannulation and sampling technique widely used in pigs (Stein et al., 1998) to 15-d-old calves and to evaluate the effect of the cannulation procedure on growth and health of calves. Our second objective was to characterize the flow of ileal digesta $\mathrm{pH}$ by applying a brokenline regression model to the data. To our knowledge, the opportunities provided by this model have not been explored extensively in calves or in other biological models (Shafii et al., 1990; Robbins et al., 2006).

The Institutional Animal Care and Use Committee at the University of Illinois at Urbana-Champaign approved all animal procedures (protocol no. 15167). Six male Holstein calves were acquired from a commercial dairy farm and enrolled at approximately $2 \mathrm{~d}$ of age. Calves were blocked by BW and assigned randomly to either treatment (cannulation) or control (no cannulation). One of the calves in the control group died at 8 $\mathrm{d}$ due to a clostridial infection and was not replaced. Calves were housed individually outdoors in polyvinyl chloride hutches that were bedded with straw. All calves were fed $2 \times$ daily a commercial milk replacer $(28.5 \%$ CP, $15 \%$ fat) reconstituted to $15 \%$ solids, at a rate of $2 \%$ (DM) of BW daily, adjusted weekly. A texturized calf starter $(20 \%$ CP) was offered for ad libitum intake only from wk 6 until the end of the trial to verify that the amount of digesta collected during the milk-only phase was sufficient for nutrient analysis. Weaning started on d 49 by progressive dilution of milk replacer until the end of the trial (d 56). Body weight and body frame measurements were recorded weekly, and water, milk, and starter intakes were measured daily.

Surgery was performed on d 15 after arrival. Calves were not fed the morning of the surgery to avoid seepage of gastrointestinal contents into the abdominal cavity. However, a solution (2 L/calf) containing electrolytes was offered to keep calves properly hydrated. Antibiotic injections of penicillin $(22,000 \mathrm{IU} / \mathrm{kg})$ were administered at $24 \mathrm{~h}, 12 \mathrm{~h}$, and immediately before the surgery. Immediately before surgery, an analgesic (flunixin meglumine) was injected intravenously at a dose of $1 \mathrm{~mL} / 45 \mathrm{~kg}$ of BW. Calves were anesthetized with xylazine $(0.15 \mathrm{mg} / \mathrm{kg}$ of BW) and ketamine $(3 \mathrm{mg} / \mathrm{kg}$ of BW) combined in a single intravenous injection, followed by immediate endotracheal intubation. Anesthesia was maintained with isoflurane $(2-5 \%$ isoflurane in oxygen) using mechanical ventilation. The incision area was shaved with an electric razor and then cleansed with repeated applications of alcohol and povidone-iodine. Sterile drapes were used to protect the surgery site. A sterile scalpel was used to make an incision through the skin layer approximately $4 \mathrm{~cm}$ posterior to the last rib on the right side of the animal. Muscle layers were mechanically separated by hand, exposing the peritoneum. A scalpel was used to carefully cut the peritoneum and locate the intestinal area approximately $5 \mathrm{~cm}$ anterior to the ileocecal junction, where the incision for the $\mathrm{T}$ cannula was to be made. A purse string suture was then inserted into the submucosa of the ileum using $2 / 0$ absorbable chromic gut suture, and a 4-cm incision in the intestine was made inside the purse string. A titanium T-cannula, designed as described by Stein et al. (1998), was inserted into the opening and the suture was pulled tight to secure the cannula. A second reinforcing suture using 2/0 absorbable chromic gut was used to further secure the cannula. The barrel of the cannula was exteriorized through a stab wound anterior to the original incision. The cannula was pulled through this incision with the aid of tissue forceps. A plastic washer and a metal lock washer were screwed onto the threaded barrel to secure the exteriorized cannula, and a cap was placed on the top of the cannula to prevent digesta seepage. Penicillin was dripped into the body cavity (approximately $1 \mathrm{~mL} / 10 \mathrm{~kg}$ of $\mathrm{BW}$ ) through the initial incision to reduce the risk of tissue infection. The peritoneum layer was closed with $2 / 0$ absorbable chromic gut suture in a continual pattern. Muscle, fat, and skin layers were sewn in an interrupted pattern using 0/0 synthetic absorbable suture. Each surgery took approximately $20 \mathrm{~min}$. Once calves had recovered from the anesthesia, they were moved back to their hutches. Analgesics were administered intravenously for $3 \mathrm{~d}$ and penicillin for $7 \mathrm{~d}$ after the surgery, every 
12 h. An ointment with $1 \%$ chlorhexidine (Nolvasan, Zoetis Inc., Parsippany, NJ) was applied to the incision site, which was sprayed with an aluminum-based aerosol bandage (AluShield, Neogen, Lexington, KY) immediately following surgery. In addition, the area of the incision site and the skin around the cannula were washed with povidone-iodine solution, and a zinc oxidelanolin-based cream (Desitin, Pfizer Inc., New York, $\mathrm{NY}$ ) was applied twice daily or more often if needed to minimize irritation and maintain skin integrity during the experiment. Animals returned to full feeding the evening of the day of the surgery. Calves were offered an electrolyte solution $(\sim 2 \mathrm{~L} / \mathrm{d}$ per calf $)$ between meals (at $1200 \mathrm{~h}$ ) during the initial $15 \mathrm{~d}$ postsurgery. Body temperature was monitored 3 times daily for the initial $7 \mathrm{~d}$ postsurgery and daily thereafter.

After the 2-wk recovery period, digesta samples were collected in weekly periods for 4 wk. During each sampling period, a 250-mL plastic bag (Playtex, North Bergen, NJ) was attached to the cannula with an autolocking cable tie after removing the cap. Bags were removed when full or every 30 min continuously for 12 $\mathrm{h}$ (between the a.m. and p.m. meals) for 2 consecutive days. The contents of each bag were weighed, the digesta $\mathrm{pH}$ was recorded immediately with a portable pH meter (Accumet AP110, Fisher Scientific, Atlanta, GA), and the digesta sample was frozen at $-20^{\circ} \mathrm{C}$. Samples were pooled within calf by week. Cannulated calves were killed at $56 \mathrm{~d}$ of age.

Variables for BW, body frame measurements, and intakes recorded during the $6 \mathrm{wk}$ after the surgery (starting at d 15) were analyzed using PROC MIXED in SAS (version 9.4; SAS Institute Inc., Cary, NC) including the REPEATED statement. The covariance structure that resulted in the smallest Bayesian and Akaike information criterion was chosen. Treatment, week, and their interaction were included as fixed effects, and calf was included as a random effect. Initial values (at wk 2) were included as covariates. Weekly $\mathrm{BW}$ and $\mathrm{pH}$ values were fit to the best broken-line model based on the adjusted coefficient of determination values, significance of the parameter estimates, and visual appraisal of the residuals using NLREG (version 6.5; http://www.nlreg .com/). Weekly BW increase was fitted in a broken-line model according to the equation

$$
\begin{gathered}
\mathrm{BW}=\left[\mathrm{b}_{1} \times \operatorname{maximum}\left(0, \text { age }-\mathrm{c}_{1}\right)\right] \\
+\left[\mathrm{a}_{0}+\left(\mathrm{b}_{2}-\mathrm{b}_{1}\right) \times \operatorname{minimum}\left(\text { age }, \mathrm{c}_{2}\right)\right],
\end{gathered}
$$

where $a_{0}$ is the intercept (initial BW), $b_{1}$ and $b_{2}$ represent the different growth slopes, $c_{1}$ and $c_{2}$ represent the time points that delimit a change in slope, and age is the week of life. A set of dummy variables was created to compare parameters of the BW evolution model between cannulated and noncannulated calves. Digesta $\mathrm{pH}$ also was fitted in a broken-line model using the equation

$$
\begin{gathered}
\mathrm{pH}=\left[\mathrm{a}_{0}+\mathrm{b}_{1} \times \operatorname{maximum}\left(0, \text { time }-\mathrm{c}_{1}\right)\right] \\
+\left[\left(\mathrm{b}_{2}-\mathrm{b}_{1}\right) \times \operatorname{maximum}\left(0, \text { time }-\mathrm{c}_{2}\right)\right]
\end{gathered}
$$

where $\mathrm{a}_{0}$ is the estimate of initial $\mathrm{pH}$ at plateau, $\mathrm{b}_{1}$ and $\mathrm{b}_{2}$ are the 2 different slopes, $\mathrm{c}_{1}$ and $\mathrm{c}_{2}$ are the estimates of the time points where a significant change in slope occurs, and time is the hour postfeeding after the morning meal.

Flow of digesta samples $(46.4 \pm 0.04 \mathrm{~g} / \mathrm{h})$ tended $(P$ $=0.08$ ) to increase linearly after feeding, whereas there was a quadratic effect of time $(P<0.01)$ on digesta $\mathrm{pH}$ (Figure 1). There were no differences across weeks or between cannulated calves in fresh weight $(0.72 \pm$ $0.13 \mathrm{~kg} / \mathrm{wk}), \mathrm{DM}$ content $(12.4 \pm 1.2 \%)$, or $\mathrm{pH}(7.1 \pm$ 0.6) of digesta. According to the parameter estimates obtained after fitting $\mathrm{pH}$ of digesta samples per hour to the model (Figure 1), the initial $\mathrm{pH}$ of 7.47 was maintained until $5.45 \mathrm{~h}$ after the a.m. feeding. After that point, $\mathrm{pH}$ decreased at a rate of $0.34 \mathrm{pH}$ unit/h until $8.69 \mathrm{~h}$ postfeeding, when $\mathrm{pH}$ began to increase at a rate of 0.33 units/h. A similar fluctuation between meals has been observed in other studies with milk-fed calves (Guilloteau et al., 1986). Despite the relatively low adjusted coefficient of determination of the model (Figure 1) and the inherently high relative error when comparing pH means (Murphy, 1982), this model allowed prediction of fluctuations of ileal $\mathrm{pH}$ between meals.

Ileal digesta $\mathrm{pH}$ fluctuation can provide information about abomasal digestion of different sources of nutrients in milk replacer (Guilloteau et al., 1986). For instance, the time it takes the first chyme that leaves the abomasum to reach the ileum after feeding could be identified as the break point estimate representing the first decrease in baseline $\mathrm{pH}\left(\mathrm{c}_{1}=5.45 \mathrm{~h}\right)$ because the digesta passing through at that moment carries the acid from gastric digestion. Assuming a constant transit across the small intestine, this parameter would allow us to evaluate differences on timing of the abomasal release of digesta. Factors such as the presence or not of curd formation in the abomasum modify abomasal flow between different milk replacer components (Petit et al., 1987). In addition, considering the relation between fluctuation of abomasal digesta $\mathrm{pH}$ and abomasal outflow (Sen et al., 2006), abomasal emptying duration could be roughly estimated by measuring the time that digesta $\mathrm{pH}$ remained lower- that is, from the $\mathrm{pH}$ at the initial plateau until the end of the negative slope 


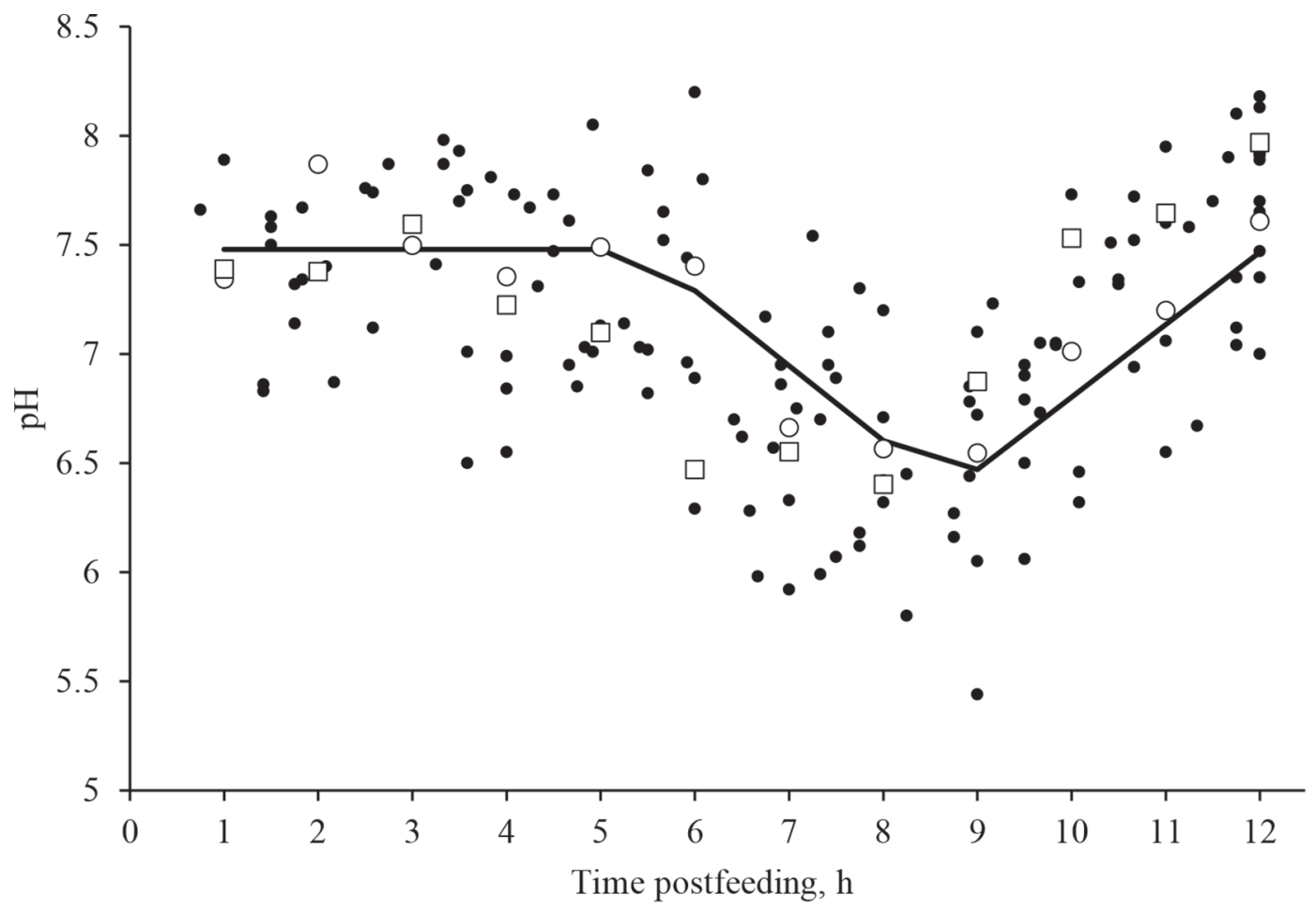

- $\mathrm{pH}$ per sample $\bigcirc$ Calf $1 \quad \square$ Calf $2 \quad$ Broken-line regression

Figure 1. Ileal digesta $\mathrm{pH}$ fluctuation during $12 \mathrm{~h}$ after the morning feeding (milk replacer only) during 4 weekly collection periods from wk 4 to 8 of life. Digesta pH per sample $(\bullet)$ was averaged by calf and hour $(O=$ calf $1 ; \square=$ calf 2$)$ to estimate the nonlinear broken-line model parameters; $\mathrm{pH}=\left[\mathrm{a}_{0}+\mathrm{b}_{1} \times \operatorname{maximum}\left(0\right.\right.$, time $\left.\left.-\mathrm{c}_{1}\right)\right]+\left[\left(\mathrm{b}_{2}-\mathrm{b}_{1}\right) \times \operatorname{maximum}\left(0\right.\right.$, time $\left.\left.-\mathrm{c}_{2}\right)\right] ; \mathrm{R}^{2}=0.7, P<0.01$. According to this equation, parameter estimates were as follows: initial $\mathrm{pH}\left(\mathrm{a}_{0}\right)=7.47$; time at $\mathrm{pH}$ decrease $\left(\mathrm{c}_{1}\right)=5.45 \mathrm{~h}$; decreasing slope $\left(\mathrm{b}_{1}\right)=-0.34 \mathrm{pH}$ unit/h; time at $\mathrm{pH}$ increase $\left(\mathrm{c}_{2}\right)=8.69 \mathrm{~h}$; and increasing slope $\left(\mathrm{b}_{2}\right)=0.33 \mathrm{pH}$ unit $/ \mathrm{h}$.

$\left(\mathrm{c}_{2}-\mathrm{c}_{1}=4.05 \mathrm{~h}\right)$. According to the literature, abomasal emptying time following $2 \mathrm{~L}$ of milk replacer intake is between 3.16 and $3.43 \mathrm{~h}$ (Nouri and Constable, 2006; Sen et al., 2006; Marshall et al., 2008). Because feeding larger volumes of milk may slow abomasal emptying (Burgstaller et al., 2017), our estimate of $4.05 \mathrm{~h}$ seems appropriate considering we fed an average of $4 \mathrm{~L}$ per feeding. This estimate may be a beneficial parameter to record in digestibility experiments because of the effect that different milk replacer ingredients may have in changing abomasal emptying rate and its implications on nutrient digestion and digestive health (Burgstaller et al., 2017).

Even though continuous collection of digesta during $12 \mathrm{~h}$ seems to be a good procedure to capture the entire daily fluctuation of digesta $\mathrm{pH}$, restricting the collection of digesta to a reduced interval of time can be sufficient to measure ileal digestibility. Kim et al. (2016) found in ileal-cannulated pigs that $6 \mathrm{~h}$ of continuous collection starting 4 or $6 \mathrm{~h}$ after feeding provided similar estimates of standard ileal digestibilities of AA compared with a 12 -h continuous collection period. A shorter collection period would reduce considerably the labor requirement, but further research is needed to assess whether shorter sampling intervals can be applied to milk-fed calves.

One cannulated calf died on d 4 postsurgery due to a fibrinous peritonitis in the peritoneal cavity. Therefore, at the beginning of the measuring period, there were only 2 calves in each group $(n=2)$. We acknowledge the limitations of the small number of calves; however, we compared intakes and growth between cannulated calves and paired noncannulated calves. Initial BW, mean BW, ADG, milk replacer intake, and water intake were not affected by cannulation (Table 1 ). However, final BW was lower $(P=0.05)$ and starter intake tended $(P=0.06)$ to be lower in cannulated calves. Differences in starter intake occurred because one of the cannulated calves did not consume any solid feed during the trial. There were no effects on health (fecal, nasal, respiratory, and ear scores), rectal temperature, or the odds of incurring diarrhea $(P=0.57)$ or being medicated $(P$ $=0.35)$. The broken-line regression model (Equation 1 ) adequately fit the BW data set, explaining $99 \%$ of the 
Table 1. Least squares means and parameter estimates for effects of ileal cannulation on rectal temperature, intake, and BW

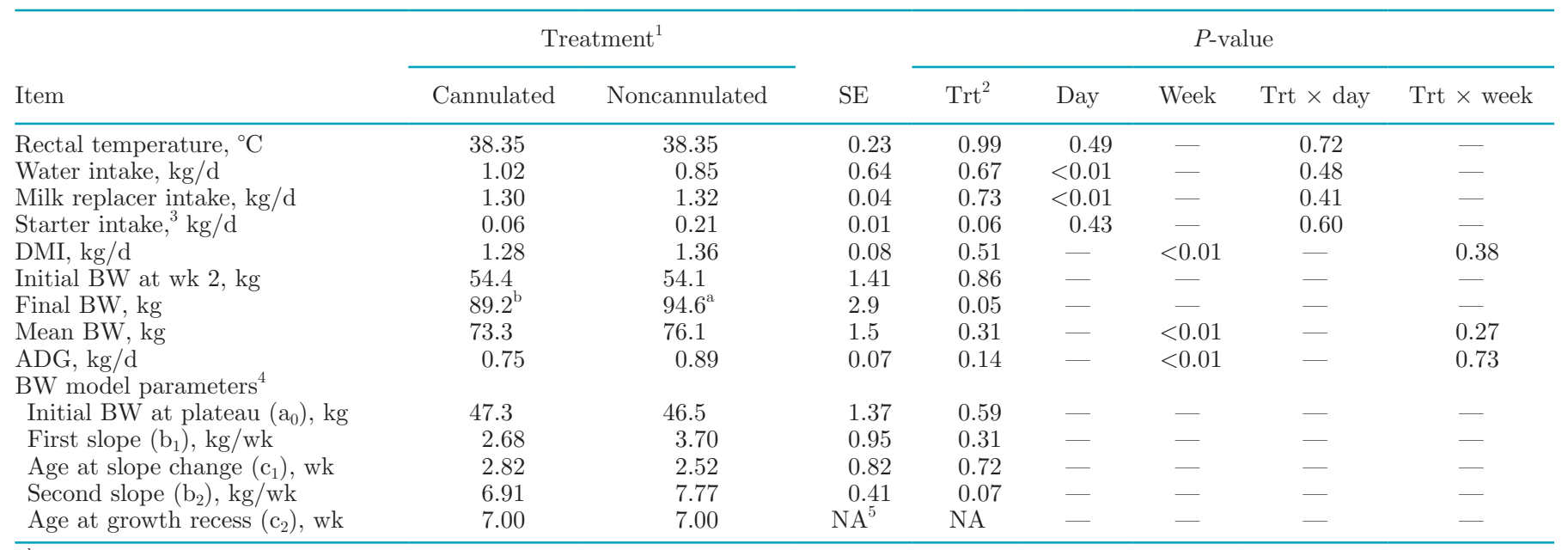

${ }^{\mathrm{a}, \mathrm{b}}$ Means within a row with different superscripts differ $(P<0.05)$ between main effect treatment.

${ }^{1}$ Two calves were cannulated on d 15 of life, and 2 noncannulated calves were used as controls. Both groups were fed milk replacer at a rate of $2 \%$ (DM basis) of BW daily.

${ }^{2}$ Treatment.

${ }^{3}$ Starter was offered from wk 6 .

${ }^{4}$ Estimates of the parameters from Equation 1.

${ }^{5} \mathrm{NA}=$ not applicable.

variation. Comparison of the model parameters revealed a tendency for a slower rate of growth in cannulated calves after approximately $2.5 \mathrm{wk}$, which reflected the effect of surgery during their second week of life (Table 1 ), in agreement with the difference in final BW found with the mixed linear model analysis.

The broken-line regression approach allowed parameterization of both growth and $\mathrm{pH}$ models. Broken-line regression models usually have been used to estimate nutrient requirements in dose-response studies (Robbins et al., 2006) because the break point or knot estimates allow identification of when a significant change in slope exists. The same principle can be applied when measuring the response to a continuous variable such as temperature (Hammami et al., 2013) or time, as we did in this analysis. In our study, the broken-line regression was a convenient tool to evaluate the growth rate after surgery and could help identify differences in $\mathrm{pH}$ fluctuation and digesta flow between diets in future experiments.

Despite an expected negative effect on final BW and growth rate after surgery, the cannulation and sampling technique permitted collection of sufficient ileal digesta while allowing satisfactory growth and health of the calves. Unlike methodology applied in the past such as re-entrant cannulas (Markowitz et al., 1964) or continuous milk replacer infusion into the abomasum (Montagne et al., 2000), continuous collection of digesta between meals is a convenient technique that reduces labor requirement and minimally disrupts the regular behavior and digestive transit of the calves. In addition, the collection method used in the current experiment seems to provide reliable data for digestive tract transit between meals because it allowed an accurate depiction of fluctuation of $\mathrm{pH}$ in the digesta reaching the distal ileum between meals. The $\mathrm{pH}$ fluctuation patterns are an important component of understanding dietary effects on digestion and could be used to estimate abomasal emptying rate, among other parameters.

\section{ACKNOWLEDGMENTS}

This work was supported by state and federal funds allocated to the Illinois Agricultural Experiment Station (Urbana, IL) and a gift from Hamlet Protein A/S (Horsens, Denmark).

\section{REFERENCES}

Baldwin, R. L., K. R. McLeod, J. L. Klotz, and R. N. Heitmann. 2004. Rumen development, intestinal growth and hepatic metabolism in the pre- and postweaning ruminant. J. Dairy Sci. 87:E55-E65. https://doi.org/10.3168/jds.S0022-0302(04)70061-2.

Burgstaller, J., T. Wittek, and G. W. Smith. 2017. Invited review: Abomasal emptying in calves and its potential influence on gastrointestinal disease. J. Dairy Sci. 100:17-35. https://doi.org/10 .3168/jds.2016-10949.

Cervantes-Pahm, S. K., and H. H. Stein. 2010. Ileal digestibility of amino acids in conventional, fermented, and enzyme-treated soybean meal and in soy protein isolate, fish meal, and casein fed to weanling pigs. J. Anim. Sci. 88:2674-2683. https://doi.org/10 $.2527 /$ jas.2009-2677. 
Drackley, J. K. 2008. Calf nutrition from birth to breeding. Vet. Clin. North Am. Food Anim. Pract. 24:55-86. https://doi.org/10.1016/ j.cvfa.2008.01.001.

Eckert, E., H. E. Brown, K. E. Leslie, T. J. DeVries, and M. A. Steele. 2015. Weaning age affects growth, feed intake, gastrointestinal development, and behavior in Holstein calves fed an elevated plane of nutrition during the preweaning stage. J. Dairy Sci. 98:6315-6326. https://doi.org/10.3168/jds.2014-9062.

Górka, P., Z. M. Kowalski, R. Zabielski, and P. Guilloteau. 2018. Invited review: Use of butyrate to promote gastrointestinal tract development in calves. J. Dairy Sci. 101:4785-4800. https://doi .org/10.3168/jds.2017-14086.

Gorrill, A. D. L., and J. W. G. Nicholson. 1972. Effects of neutralizing acid whey powder in milk replacers containing milk and soybean proteins on performance and abomasal and intestinal digestion in calves. Can. J. Anim. Sci. 52:465-476. https://doi.org/10.4141/ cjas72-055.

Gro Intelligence. 2017. Can soy protein become the next whey? Accessed Dec. 4, 2018. https://gro-intelligence.com/insights/soy -protein-next-whey-protein.

Guilloteau, P., R. Toullec, J. F. Grongnet, P. Patureau-Mirand, J Prugnaud, and D. Sauvant. 1986. Digestion of milk, fish and soyabean protein in the preruminant calf: Flow of digesta, apparent digestibility at the end of the ileum and amino acid composition of ileal digesta. Br. J. Nutr. 55:571-592.

Hammami, H., J. Bormann, N. M'hamdi, H. H. Montaldo, and N. Gengler. 2013. Evaluation of heat stress effects on production traits and somatic cell score of Holsteins in a temperate environment. J. Dairy Sci. 96:1844-1855. https://doi.org/10.3168/jds.2012-5947.

Hill, T. M., H. G. Bateman, J. M. Aldrich, R. L. Schlotterbeck, and K. G. Tanan. 2008. Optimal concentrations of lysine, methionine, and threonine in milk replacers for calves less than five weeks of age. J. Dairy Sci. 91:2433-2442. https://doi.org/10.3168/jds.2007-0610.

Hurley, D., J. Hussey, R. Mckeown, and C. Addy. 2006. An evaluation of splines in linear regression. Page 147 in SAS Conference Proceedings: SAS Users Group International 31, San Francisco, CA. SAS Institute Inc., Cary, NC.

Khorasani, G. R., L. Ozimek, W. C. Sauer, and J. J. Kennelly. 1989 Substitution of milk protein with isolated soy protein in calf milk replacers. J. Anim. Sci. 67:1634-1641.

Kim, B. G., Y. Liu, and H. H. Stein. 2016. Effects of collection time on flow of chromium and dry matter and on basal ileal endogenous losses of amino acids in growing pigs. J. Anim. Sci. 94:4196-4204. https://doi.org/10.2527/jas.2015-0248.

Lallès, J. P. 1993. Nutritional and antinutritional aspects of soyabean and field pea proteins used in veal calf production: A review. Livest. Prod. Sci. 34:181-202. https://doi.org/10.1016/0301 -6226(93)90106-R

Lallès, J. P., H. M. Tukur, P. Salgado, E. N. Mills, M. R. Morgan, L. Quillien, D. Levieux, and R. Toullec. 1999. Immunochemical studies on gastric and intestinal digestion of soybean glycinin and beta-conglycinin in vivo. J. Agric. Food Chem. 47:2797-2806.

Markowitz, J., J. Archibald, and H. G. Downie. 1964. Experimental Surgery. 5th ed. Williams \& Wilkins, Baltimore, MD.

Marsh, L. C., and D. R. Cormier. 2002. Spline Regression Models. Sage, Thousand Oaks, CA.

Marshall, T. S., P. D. Constable, S. S. Crochik, T. Wittek, D. E. Freeman, and D. E. Morin. 2008. Effect of suckling an isotonic solution of sodium acetate, sodium bicarbonate, or sodium chloride on abomasal emptying rate and luminal $\mathrm{pH}$ in calves. Am. J. Vet. Res. 69:824-831. https://doi.org/10.2460/ajvr.69.6.824.

Meale, S. J., F. Chaucheyras-Durand, H. Berends, L. L. Guan, and M. A. Steele. 2017. From pre- to postweaning: Transformation of the young calf's gastrointestinal tract. J. Dairy Sci. 100:5984-5995. https://doi.org/10.3168/jds.2016-12474.
Montagne, L., I. Crévieu-Gabriel, R. Toullec, and J. P. Lallès. 2003 Influence of dietary protein level and source on the course of protein digestion along the small intestine of the veal calf. J. Dairy Sci. 86:934-943. https://doi.org/10.3168/jds.S0022-0302(03)73676 -5 .

Montagne, L., R. Toullec, M. Formal, and J. P. Lallès. 2000. Influence of dietary protein level and origin on the flow of mucin along the small intestine of the preruminant calf. J. Dairy Sci. 83:2820-2828. https://doi.org/10.3168/jds.S0022-0302(00)75181-2.

Murphy, M. R. 1982. Analyzing and presenting pH data. J. Dairy Sci 65:161-163. https://doi.org/10.3168/jds.S0022-0302(82)82165-6.

Nouri, M., and P. D. Constable. 2006. Comparison of two oral electrolyte solutions and route of administration on the abomasal emptying rate of Holstein-Friesian calves. J. Vet. Intern. Med. 20:620-626.

Petit, H. V., M. Ivan, and G. J. Brisson. 1987. Duodenal flow of digesta in preruminant calves fed clotting or nonclotting milk replacer. J. Dairy Sci. 70:2570-2576. https://doi.org/10.3168/jds.S0022 $-0302(87) 80326-0$

Rey, M., F. Enjalbert, and V. Monteils. 2012. Establishment of ruminal enzyme activities and fermentation capacity in dairy calves from birth through weaning. J. Dairy Sci. 95:1500-1512. https:// doi.org/10.3168/jds.2011-4902.

Robbins, K. R., A. M. Saxton, and L. L. Southern. 2006. Estimation of nutrient requirements using broken-line regression analysis. J. Anim. Sci. 84(Suppl.):E155-E165. https://doi.org/10.2527/2006 .8413_supple155x.

Schäff, C. T., J. Gruse, J. Maciej, R. Pfuhl, R. Zitnan, M. Rajsky, and H. M. Hammon. 2018. Effects of feeding unlimited amounts of milk replacer for the first 5 weeks of age on rumen and small intestinal growth and development in dairy calves. J. Dairy Sci. 101:783-793. https://doi.org/10.3168/jds.2017-13247.

Schwarz, C. J. 2015. Regression-Hockey sticks, broken sticks, piecewise, change points. Pages 1126-1142 in Course Notes for Beginning and Intermediate Statistics. Department of Statistics and Actuarial Science, Simon Fraser University, Burnaby, BC, Canada.

Sen, I., P. D. Constable, and T. S. Marshall. 2006. Effect of suckling isotonic or hypertonic solutions of sodium bicarbonate or glucose on abomasal emptying rate in calves. Am. J. Vet. Res. 67:13771384. https://doi.org/10.2460/ajvr.67.8.1377.

Senevirathne, N. D., J. L. Anderson, W. R. Gibbons, and J. A. Clapper. 2017. Growth performance of calves fed microbially enhanced soy protein in pelleted starters. J. Dairy Sci. 100:199-212. https: /doi.org/10.3168/jds.2016-11221.

Shafii, B., K. C. Harper, and S. L. Mcgeehan. 1990. Linear-plateau regression analysis and its application to selenite adsorption rate. Pages 106-119 in Proc. Conf. Applied Statistics in Agriculture. Kansas State University, Manhattan, KS.

Smith, R. H. 1962. Net exchange of certain inorganic ions and water in the alimentary tract of the milk-fed calf. Biochem. J. 83:151-163. https://doi.org/10.1042/bj0830151.

Stein, H. H., B. Sève, M. F. Fuller, P. J. Moughan, and C. F. M. De Lange. 2007. Invited review: Amino acid bioavailability and digestibility in pig feed ingredients: Terminology and application. J. Anim. Sci. 85:172-180. https://doi.org/10.2527/jas.2005-742.

Stein, H. H., C. F. Shipley, and R. A. Easter. 1998. Technical note: A technique for inserting a T-cannula into the distal ileum of pregnant sows. J. Anim. Sci. 76:1433-1436. https://doi.org/10.2527/ 1998.7651433x

Warner, R. G., W. P. Flatt, and J. K. Loosli. 1956. Ruminant nutrition, dietary factors influencing development of ruminant stomach. J. Agric. Food Chem. 4:788-792. https://doi.org/10.1021/ jf60067a003. 